\title{
Harmonious Values of Kupatan Tradition on Plosokandang Society, Tulungagung
}

\author{
Khabibur Rohman \\ Universitas Islam Negeri Sayyid Ali Rahmatullah Tulungagung, Indonesia \\ haabib.rohman@gmail.com \\ Moh. Irsyad Fahmi Malik Rahma \\ Universitas Islam Negeri Sayyid Ali Rahmatullah Tulungagung, Indonesia \\ fahmienchanter@gmail.com \\ Nailul Wirdah \\ Al-Azhar University, Cairo, Egypt \\ nailulimtiyaz@gmail.com
}

\begin{abstract}
This article aims to draw a comprehensive overview of some values in the Kupatan tradition on Plosokandang society, Tulungagung. The current research implements descriptive analysis; meanwhile, the data collection method is the interview, observation, and documentation. Kupatan is one tradition that happens for the reason of as a celebration that occurs after Eid al-Fitr. Kupatan on Plosokandang-Tulungagung is always held on the seventh day of Shawwal or seven days after Eid. The result of the study shows that there is a value of harmony among society while applying kupatan. During kupatan, the people of Plosokandang distributed some kupat and various traditional foods to everyone who came to visit at this event who they did not even know before. Moreover, the value of social harmony contained in the activity of Kupatan not only according to Islam but is also needed for a multicultural country like Indonesia.
\end{abstract}

\section{(c) $(1) \Theta$}

DOI: 10.19105/karsa.v29i1.3781 
[Artikel ini bertujuan untuk memberikan gambaran yang komprehensif dari hasil analisis nilai-nilai yang terdapat pada kegiatan kupatan pada masyarakat Plosokandang, Tulungagung. Metode analisis yang digunakan yaitu analisis deskriptif, sedangkan metode pengumpulan data menggunakan wawancara, observasi, dan studi dokumen. Kupatan merupakan salah satu perayaan yang mengiringi Hari Raya Idul Fitri. Kupatan pada masyarakat Plosokandang-Tulungagung, selalu diadakan pada hari ketujuh Bulan Syawal atau tujuh hari setelah Idul Fitri. Hasil kajian menunjukkan bahwa pada kegiatan kupatan yang dilaksanakan masyarakat Plosokandang, Tulungagung, sangat kental terhadap nilai kerukunan. Masyarakat Plosokandang pada kegiatan Kupatan, membagikan ketupat dan aneka makanan tradisional kepada setiap orang yang datang berkunjung yang bahkan mereka tidak kenal sebelumnya. Nilai kerukunan pada kegiatan kupatan tidak hanya sejalan dengan ajaran agama Islam, tetapi juga dibutuhkan bagi negara multikultural seperti Indonesia.]

Keywords: harmony; kupatan; tradition

\section{Introduction}

As one of some holy days on Islam, Eid al-Fitr is always celebrated by all Muslims from various countries. Meanwhile, in celebrating Eid al-Fitr, each country has a different way. The difference in celebrating Eid al-Fitr is influenced by several things such as culture, socio-economy, and climate in each country. Each society has various logic or various way on how to realize the cultures which affected by their locality, which then is believed as truth. ${ }^{1}$

Muslims in Turkey celebrate Eid Al-Fitr with the Seker Bayram tradition, which is the tradition of sharing sweets, chocolate, coins, and

\footnotetext{
1 Koentjaraningrat, Kebudayaan: Mentalitas dan Pembangunan (Jakarta: PT. Gramedia Pustaka Utama, 2000); Muhamad Ali, "Muslim Diversity: Islam and Local Tradition in Java and Sulawesi, Indonesia," Indonesian Journal of Islam and Muslim Societies 1, no. 1 (2011): 1-35, https://doi.org/10.18326/ijims.v1i1.1-35; A. I. Sinaga, "Islamic Culture and Culture of Islam (As a Reflection in Rediscovering of Standard Absorption of Culture in Islamic Teaching)," Journal of Humanities and Social Science 21, no. 5 (2016): 90-95, https://doi.org/10.9790/0837-2105029095.
}

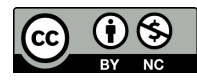

DOI: $10.19105 /$ karsa.v29i1.3781 
some traditional foods such as lokum and baklava to children. The Muslim community in China celebrates Eid Al-Fitr by visiting the graves of ancestors, or the graves of local Muslim figures, such as the most famous one is Sayyid Ajjal, a Muslim figure who also served as Governor of Yunnan Province, China. ${ }^{2}$ Saudi Arabian Muslims celebrate Eid by holding various artistic performances such as theater performances, poetry readings, music parades, dances, and various other artistic performances. Meanwhile, in several countries in Southeast Asia, such as Indonesia, Malaysia, Thailand, and Brunei Darussalam, the tradition is a homecoming to their hometown. ${ }^{3}$

In most sections of Indonesia, Eid al-Fitr is celebrated with homecoming activities, Sungkeman, and serving various foods and cakes. ${ }^{4}$ One of the foods that are synonymous with the celebration of Eid al-Fitr in Indonesia is ketupat and chicken opor. This activity of cooking, serving, and distributing ketupat is what people in several regions in Indonesia called as Kupatan. Currently, ketupat is no longer only found in Indonesia, and several countries have also recognized this

\footnotetext{
2 Hew Wai Weng, "Beyond Chinese Diaspora" and "Islamic Ummah": Various Transnational Connections and Local Negotiations of Chinese Muslim Identities in Indonesia," Sojourn: Journal of Social Issues in Southeast Asia 29, no. 3 (2014): 62756, https://doi.org/10.1355/sj29-3d.

${ }^{3}$ Sri Hariyatmi, "Food: Invisible Bridge Connecting The Past and Present Day of Diasporic Identity," CELTIC: A Journal of Culture, English Language Teaching, Literature \& Linguistics 6, no. 2 (2019): 42-50, https://doi.org/https://doi.org/ 10.22219/celtic.v6i2.9934; Carl B. McGowan, Jr. and Noor Azzudin Jakob, "Is There An Eid Al-Fitr Effect In Malaysia?," International Business \& Economics Research Journal (IBER) 9, no. 4 (2010): 11-20, https://doi.org/10.19030/iber.v9i4.549; Harit Satt, "Eid Mawlid Al-Nabi, Eid Al-Fitr and Eid Al-Adha; Optimism and Impact on Analysts' Recommendations: Evidence From MENA Region," Arab Economic and Business Journal 12, no. 1 (2017): 57-67, https://doi.org/10.1016/j.aebj.2017.04.001.

${ }^{4}$ Samsubar Saleh, Dyah Titis Kusuma Wardani, and Madha Adi Ivantri, "Ramadhan, Eid U1 Fitr, and Inflation: Lesson From Indonesian Subnational Data," Jurnal Ekonomi \& Studi Pembangunan 20, no. 2 (2019): 135-50, https://doi.org/10.18196/jesp.20.2. 5020; Sherley Yurike and Sukmawati Sukamulja, "Eid Al-Fitr Holiday Effect And The Relation Between Eid Al-Fitr Holiday Effect With The Firm Size During 2000 To 2013," Jurnal Ekonomi Manajemen Internasional 53, no. 9 (2013): 1-12, http://ejournal.uajy.ac.id/6986/1/JURNAL.pdf.
}

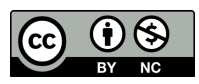

DOI: 10.19105/karsa.v29i1.3781 
food as a portion of food served during the celebration of Eid al-Fitr. Some of these countries include Brunei, Malaysia, the Philippines, and Singapore. ${ }^{5}$

Kupatan is generally held on the seventh day of the month of Shawwal (is the tenth month of the lunar based Islamic calendar), or a week after Idul Fitri. However, in the details of its implementation, each local wisdom or region has a different style and timing. The differences mainly exist in the form of activity, place, and motive for the implementation. Kupatan in Tulungagung begins on the seventh day of the month of Shawwal and can be held for several days. This activity was very lively because it involved people from various backgrounds, the excitement of Kupatan can be compared to the implementation of Eid al-Fitr.

This article then aims to study the values contained in Kupatan tradition on Plosokandang society, Tulungagung. Kupatan in Tulungagung was chosen as the object of research, by considering under the reasons of, Kupatan in Tulungagung, especially on Plosokandang, were unique when compared to similar activities in other districts. Especially in terms of implementation, time, and place.

Previously, there were several articles that were conducted on taking Kupatan as the object of research. Among them, Yuliati focuses on the value of mutual cooperation in Kupatan, ${ }^{6}$ which sees Kupatan as a means of giving charity, connecting relationships, and honoring guests. Meanwhile, Arif and Lasantu examine the value of education in Kupatan, ${ }^{7}$ Nurcahyo and Yulianto see Kupatan as a cultural and tourism asset.

\footnotetext{
${ }^{5}$ Wahyuni Mulyawati and Ilse Harahap, Resep Andalan Resto Indonesia: Lontong \& Ketupat (Jakarta: PT. Gramedia Pustaka Utama., 2008).

${ }^{6}$ Wildan Rijal Amin, "Kupatan, Tradisi untuk Melestarikan Ajaran Bersedekah, Memperkuat Tali Silaturahmi, dan Memuliakan Tamu," Al-A'raf: Jurnal Pemikiran Islam Dan Filsafat 14, no. 2 (2017): 267, https://doi.org/10.22515/ajpif.v14i2.893.

${ }^{7}$ Muhammad Arif and Melki Yandi Lasantu, "Nilai Pendidikan dalam Tradisi Lebaran Ketupat Masyarakat Suku Jawa Tondano di Gorontalo," Madani 1, no. 2 (2019), https://journal.iaingorontalo.ac.id/index.php/md/article/view/1068.
}

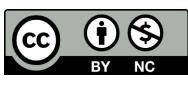

DOI: $10.19105 /$ karsa.v29i1.3781 
Meanwhile, the discussion below is for some articles that focus on the values of harmony, which were found by the researchers. ${ }^{8}$ In his writing entitled "Concept and Actualization of Interreligious Harmony", state that harmony is part of religious command; every religion teaches the importance of maintaining harmony even though they have different beliefs. There are also some studies that identify the inhibiting factors for the occurrence of inter-religious harmony, which is at once for some efforts to create harmony as society's attitudes and behavior for multireligious communities. ${ }^{9}$

Whereas, another study related to moral values contained in tradition is done by Fidiyani. Fidiyani describes several traditions in the Aboge community that appreciates the differences and fertilizes some tolerance. ${ }^{10}$ Furthermore, there is a research conducted by Abdullah \& Wijaya, ${ }^{11}$ he provides some critics and suggestions for the inadequacy of several laws and regulations designed to create harmony in Indonesia. To differentiate, then this study presents an overview of the value of harmony in the Kupatan tradition on Plosokandang society, Tulungagung.

\section{Methods}

This research implements descriptive-qualitative analysis. The researchers describe the results of the analysis of Kupatan activities on

\footnotetext{
${ }^{8}$ Toto Suryana, "Konsep dan Aktualisasi Kerukunan Antarumat Beragama," Jurnal Pendidikan Agama Islam: Ta'lim 9, no. 2 (2011), http://jurnal.upi.edu/file/03 KONSEP_DAN_AKTUALISASI_KERUKUNAN_ANTAR_UMAT_BERAGAMA - ${ }_{-}$TOTO.pdf.

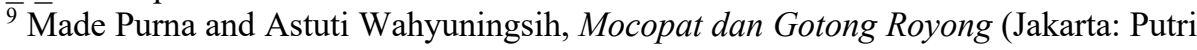
Sejati Raya, 1996).

${ }^{10}$ Rini Fidiyani, "Kerukunan Umat Beragama di Indonesia (Belajar Keharomonisan dan Toleransi Umat Beragama di Desa Cikakak, Kec. Wangon, Kab. Banyumas)," Jurnal Dinamika Hukum 13, no. 3 (2013), https://doi.org/ 0.20884/1.jdh.2013. 13.3.256.

${ }^{11}$ Zaitun Abdullah and Endra Wijaya, "Efektifitas Pengaturan Masalah Kerukunan Umat Beragama dalam Peraturan Perundang-Undangan di Indonesia," Pandecta: Jurnal Penelitian Ilmu Hukum 11, no. 2 (2016): 113-23, https://doi.org/10.15294/ pandecta.v11i1.7830.
}

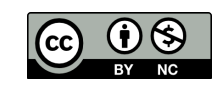

DOI: $10.19105 /$ karsa.v29i1.3781 
Plosokandang society, Tulungagung, which was obtained through observation, interview, and documentation.

\section{Results}

\section{The Implementation of Kupatan}

On the day before the Kupatan, people started to cook ketupat. This is because ketupat cooking process takes a long time. It takes between 4 and 5 hours of cooking to produce a well-cooked ketupat that can stand up to several days. In several villages, people also build some tents (terop) and a high-volume sound system to enliven the excitement of the event. ${ }^{12}$

Besides cooking ketupat and other various foods, people will also arrange tables and chairs in the agreed place. The tables next were used to serve ketupat and different foods served by society. On the day of the implementation of Kupatan, all ketupat and various traditional foods are then gathered in the prepared place. These foods next were served and neatly arranged on tables located on the side of the village road. ${ }^{13}$

After all the foods were collected and served, the event was then ready to begin. Village leaders or religious leader especially leads prayers for safety and mutual blessings. After praying together, the people then went on a trip and shook hands and asked for apologies. After that, the people of Plosokandang, Tulungagung, ate the collected food together. Everyone then did not need to eat some foods that they brought from home; instead they were free to choose the served food which brought by other people or their neighbors. ${ }^{14}$

Based on the observation results, after shaking hands and eating with the people, the excitement of the Kupatan was just about to begin.

\footnotetext{
12 Danu Bhirawa, “Kupatan Massal di Tulungagung Kian Meriah,” Harian Bhirawa, 2019, https://www.harianbhirawa.co.id/Kupatan-massal-di-tulungagung-kianmeriah/.

${ }^{13}$ Nur Hamzah Aziz, "Hari Raya Kupatan: Perspektif Filosofis dan Sosio-Kultural Masyarakat Trenggalek" (IAIN Tulungagung, 2019).

${ }^{14}$ Rizky Subagia, "Makna Tradisi Kupatan pada Masyarakat Desa Paciran, Kecamatan Paciran” (UIN Syarif Hidayatullah, 2018).
}

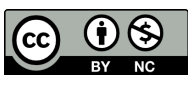


The people then offered ketupat and other foods to anyone who came from a different regency or everyone who passed by. The Kupatan event is always lively because people from other areas were able to come to eat ketupat and other foods while enjoying the excitement of the event. ${ }^{15}$

The Kupatan then ended when all of the served foods had been brought by the people, and they had been eaten and distributed. The large number of people who came to the Kupatan event made this event has not happened for a long time. At just 2 to 3 hours, all the collected foods from people then would run out and have been distributed.

\section{Discussion}

\section{The History of Kupatan}

Kupatan comes from the Javanese word kupat, which means ketupat and gets the suffix - "an" which means cooking and distributing ketupat to others. Kupat or ketupat is a food made from rice wrapped in woven young coconut leaves or janur (in Javanese). In Indonesia, ketupat is usually served with dishes such as chicken curry, rendang, lodeh, and satay. ${ }^{16}$ Ketupat was first introduced by Sunan Kalijaga, one of the nine holy men and propagators of Islam in Java, or more commonly known as Walisongo, in the $15^{\text {th }}$ century in Demak Regency, Central Java. ${ }^{17}$

Ketupat in Javanese philosophy has a special meaning. Ketupat or kupat is an acronym for "ngaku lepat", which means admitting mistakes. ${ }^{18}$ Therefore sharing ketupat in Kupatan activities is the manifestation of confessing one's mistakes to God, family and other

\footnotetext{
${ }^{15}$ Yusuf Faizal, "Nilai-Nilai Pendidikan Islam dalam Tradisi Punggahan dan Kupatan pada Masyarakat Dukuh Krangkeng Desa Grogolan Kecamatan Karanggede Kabupaten Boyolali Tahun 2014” (STAIN Salatiga, 2014).

${ }^{16}$ Yuhana and Syamsul Bahri, "Tradisi Bulan Ramadhan dan Kearifan Budaya Lokal Komunitas Jawa di Desa Tanah Datar Kecamatan Rangat Barat Kabupaten Indragirihulu," JOM Fisip 3, no. 1 (2016): 1-15, https://jom.unri.ac.id/index.php/ JOMFSIP/article/view/7966/7638.

${ }^{17}$ Yusuf and Toet, Indonesia Punya Cerita : Kebiasaan dan Kebudayaan Unik Yang Ada di Indonesia (Jakarta: Penebar Swadaya Group, 2012).

${ }^{18}$ Clifford Geertz, The Religion of Jawa (Chicago and London: The University of Chicago Press, 1976).
}

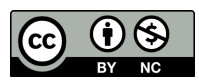

DOI: 10.19105/karsa.v29i1.3781 
people. Different sources say that the word kupat is the plural form of Arabic "kafi", which is "kuffat", wherein Indonesian means "enough". The word "enough" here means that it is enough to fast for one month during Ramadhan. ${ }^{19}$

The Kupatan itself is an activity that accompanies Eid al-Fitr, the Muslim holy day. ${ }^{20}$ Kupatan is carried out as a form of gratitude for Muslims after fasting and held in Syawal for six days after the Eid alFitr celebration. ${ }^{21}$ Through this activity, it is expected that everyone will forgive each other, cooperate with each other and establish a harmonious relationship. ${ }^{22}$

It is believed that the activity of kupatan in Tulungagung is influenced by a similar tradition carried out by the Durenan community, Trenggalek. Geographically Tulungagung and Trenggalek are located near each other, namely on the southern coast of Java Island. The activity of kupatan in Durenan Trenggalek itself is believed to have been going on for almost 200 years, started by a religious figure called the Mbah Mesir. ${ }^{23}$ Cultural interactions that occur in Tulungagung and Trenggalek can be in the form of associative (positive) relationships, for example, accommodation, assimilation, and cooperation. ${ }^{24}$

\section{The Activity of Kupatan}

The activity of Kupatan on Plosokandang Village, Tulungagung involves all people, and there is no exception, not only those who are Muslims. This shows that the activity of Tulungagung people is no longer exclusive to Muslims. All citizens, both men, and women,

\footnotetext{
${ }^{19}$ Komarudin Amin and M. Arskal Salim, Ensiklopedi Islam Nusantara: Edisi Budaya (Jakarta: Direktorat Pendidikan Tinggi Keagamaan Islam, 2018).

${ }^{20}$ Angelina Rianti et al., "Ketupat as Traditional Food of Indonesian Culture," Journal of Ethnic Foods 5, no. 1 (2018): 4-9, https://doi.org/10.1016/j.jef.2018.01.001.

${ }^{21}$ Amin, "Kupatan, Tradisi untuk Melestarikan Ajaran Bersedekah, Memperkuat Tali Silaturahmi, dan Memuliakan Tamu."

${ }^{22}$ Purna and Wahyuningsih, Mocopat dan Gotong Royong.

${ }^{23}$ Amin, "Kupatan, Tradisi untuk Melestarikan Ajaran Bersedekah, Memperkuat Tali Silaturahmi, dan Memuliakan Tamu."

${ }^{24}$ Suryono Soekanto, Sosiologi: Suatu Pengantar (Jakarta: PT. Raja Grafindo, 2003).
}

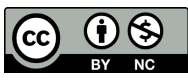

DOI: $10.19105 /$ karsa.v29i1.3781 
children and adults, are all involved and happily join in the activity of Kupatan. Even though it is called Kupatan, in this activity ketupat is not only the dish that is served; people also cook other dishes such as cenil, lontong, lepet, and of course what is not left behind is lodho which is a portion of special food from Tulungagung. ${ }^{25}$

Based on the interview, the activity of Kupatan is held on the seventh day of the month of Shawwal, or six days after the Eid al-Fitr. However, in practice, the movement of Kupatan in the Tulungagung community is not always held on that day, but according to the people's agreement. This is done to avoid "clashes" with the implementation of Kupatan in the village or other places.

As previously explained, the timing of the implementation of Kupatan in Plosokandang Village can vary from one area to another. Once again it depends on the agreement of society. Some regions carry out this activity in the morning, while some other areas carry out activities of the Kupatan at night. Diversity in the implementation of this Kupatan activity is a symbol of cultural differences that give their identity. ${ }^{26}$

If in some areas the activity of Kupatan is carried out centrally in the village hall or the local village mosque, this is not the case with Kupatan in Tulungagung. Kupatan activity is held independently by the community, which usually consists of several Rukun Tetangga (RT, smallest area of the village). The place is on the edge of village roads or intersections. Therefore, the activity of Kupatan on Plosokandang Village, Tulungagung Regency, could last more than one day in several places.

\section{Harmonious Values on Kupatan}

Every society adheres to a system of values and norms which they believe as a guide for their life. These values and norms come from

\footnotetext{
${ }^{25}$ Amin, "Kupatan, Tradisi untuk Melestarikan Ajaran Bersedekah, Memperkuat Tali Silaturahmi, dan Memuliakan Tamu."

${ }^{26}$ Erni Budiwanti, Islam Sasak: Wetu Telu versus Waktu Lima (Yogyakarta: Penerbit LKiS, 2000).
}

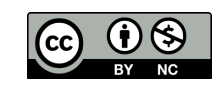

DOI: $10.19105 /$ karsa.v29i1.3781 
religious teachings, belief systems, and knowledge that comes from ancestors. These values and norms then form a local knowledge system that is used as a means of solving problems and responding to challenges that exist in the community. ${ }^{27}$ These values and norms are implemented into attitudes, behaviors, rules, literature, and various traditions.

\section{The Value of Harmony}

Etymologically, the word "rukun" or harmony comes from Arabic, namely ruknun, which if it is interpreted in Indonesian, means as a pillar, precept, or basis. The plural form of ruknun is arkaan. From the word arkaan, we can get the meaning that harmony is a mutually reinforcing unity from various different elements. ${ }^{28}$ Whereas in English, the word rukun or harmony is equated with harmonious or concord. Harmony is a social condition full of peace, and agreement minimizes disagreement (harmony, concordance). ${ }^{29}$

As a nation that believes in God, the concept of harmony is also the teaching of almost every religion and belief. Harahap reveals that in every religion and belief of holy book in Indonesia, there is a teaching to establish a harmonious relationship between human beings, no matter how many differences they have. ${ }^{30}$

The activities of Kupatan on Plosokandang of Tulungagung Regency were initially based on religious values, namely the expression of public gratitude to Allah after going through the fasting of Shawwal for six days. However, in its development, the activities of Kupatan are not only vertical, namely the relationship between humans and God, but have a more horizontal nuance, namely the relationship between human

\footnotetext{
${ }^{27}$ Nurma Ali Ridwan, “Landasan Keilmuan Kearifan Lokal," Ibda: Jurnal Studi Islam dan Budaya 5, no. 1 (2007): 27-38, https://adoc.pub/landasan-keilmuan-kearifanlokal-nurma-ali-ridwan-.html.

28 Jirhanuddin, Perbandingan Agama (Yogyakarta: Pustaka Pelajar, 2005).

${ }^{29}$ M. Ridwan Lubis, Cetak Biru Peran Agama (Jakarta: Puslitbang, 2005).

${ }^{30}$ Syahrin Harahap, Teologi Kerukunan (Jakarta: Prenada Media Media Group, 2011).
}

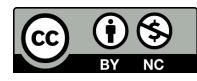

DOI: $10.19105 /$ karsa.v29i1.3781 
beings. ${ }^{31}$ Kupatan in other words, no longer has a personal dimension but has a more social dimension. ${ }^{32}$

Based on the results of observations and interviews with several sources, one of the most dominant values in Kupatan activity on Plosokandang society, Tulungagung, is the value of harmony. The success of the event in Kupatan activity was influenced by the level of cohesiveness and cooperation between people. People will discuss when and where the implementation of the activities of Kupatan, also about the division of tasks among the society, and several other matters related to the activities of the Kupatan. It was believed to increase intercommunity harmony because Kupatan event involves people from all elements, men and women, old, young and children, and even those who are not Muslims.

Kupatan can strengthen the relationship between people because during the ceremony, the people will distribute ketupat and various foods collected to those who deliberately come to visit and also those who accidentally passed. Most of those who attended and ate the dishes had never known each other before. While after eating ketupat, there will be intensive interaction between people so that harmony between society is better. The value of harmony in this Kupatan forms a cognitive community that is bound by the belief in the same essential truth. ${ }^{33}$

Highly appreciating the value of harmony as found in Kupatan, is an important value for everyone who lives in a multicultural country that applies a diversity of ethnicity, culture, and religion, such as Indonesia. ${ }^{34}$ As we understand that diversity is like a double-edged

\footnotetext{
31 Yedi Purwanto, "Memaknai Pesan Spiritual Ajaran Agama dalam Membangun Karakter Kesalehan Sosial," Jurnal Sosioteknologi 13, no. 1 (2014): 41, https://doi.org/ 10.5614/sostek.itbj.2014.13.1.5.

32 Husein Muhammad, Spiritualitas Kemanusiaan Perspektif Islam Pesantren (Bandung: Pustaka Rihlah, 2006).

33 Syamsul Arifin, Studi Agama, Perspektif Sosiologis dan Isu-Isu Kontemporer (Malang: UMM Press, 2009).

${ }^{34}$ Abd Aziz, "Desain Pendidikan Multikultural dalam Pendidikan Islam," Realita: Jurnal Penelitian dan Kebudayaan Islam 15, no. 1 (2017), https://jurnal.iainkediri. ac.id/index.php/realita/article/view/461/297.
}

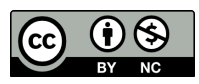

DOI: 10.19105/karsa.v29i1.3781 
knife, it has the potential to bring progress and also problems, depending on how you react. ${ }^{35}$ Based on this, it is important to ensure that the value of harmony is planted as early as possible. Harmony only can be born from a society that upholds the values of tolerance and cooperation. For this reason, in order to create a harmonious society, the values of tolerance and cooperation must be taught from the earliest age. ${ }^{36}$

Internalization of the value of harmony for children can also be done by inviting the children to interpret Kupatan. Students need to know the meaning behind Kupatan where they celebrate every year. In this way, it is expected that students will not only love and preserve Kupatan in the future but also be able to replicate the value of harmony of Kupatan in real society. ${ }^{37}$

The value of harmony contained in Kupatan is, of course, very relevant to the current condition of Indonesia, where intolerance and radicalism are such worrying problems. In addition, we have now arrived at the postmodern era or postmodern culture. ${ }^{38}$ One of the criticisms for this postmodern era is the values that have been believed and implemented by a certain society or group right now begin to fade. According to Bigovic, postmodernism is also closely related to individualism, namely secularism, or the decline in the meaning of religion. This is certainly quite contrary to the concept that has been believed so far; that is, an individual should connect to society.

This era is also signed by relatively complex, unsolved, and confusing problems. Hunger, refugees, health, war, environmental damage, trade wars, and other problems seem to have no way out. Those

\footnotetext{
35 Iis Arifudin, "Urgensi Pendidikan Multikultural di Sekolah," Insania: Jurnal Pemikiran Alternatif Pendidikan 12, no. 2 (2007), http://ejournal.iainpurwokerto.ac.id /index.php/insania/article/view/252/222.

${ }^{36}$ Radjiman Ismail, "Meningkatkan Sikap Toleransi Siswa Melalui Pembelajaran Tematik," Jurnal Ilmiah Pendidikan Islam Anak Usia Dini 2, no. 1 (2017).

37 Ang Chooi Kean and Ngu Moi Kwe, "Meaningful Learning in the Teaching of Culture: The Project Based Learning Approach," Journal of Education and Training Studies 2, no. 2 (2014): 189-97, https://doi.org/10.11114/jets.v2i2.270.

${ }^{38}$ Radovan Bigovic, The Ortodox Church in 21 St Century (Belgrade: Foundatin Konrad Adenauer, 2009).
}

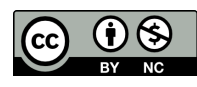


matters create a polluted society, a society in which a sense of belonging one each other and a sense for the common good disappears. ${ }^{39}$

Maintaining the tradition of Kupatan as an effort to show the value of harmony between nowadays societies is a big step to move. This is, as stated by Nye (2004), that culture has a large and significant influence on collective action among society. ${ }^{40}$

One medium that is deemed effective to maintain the value of harmony for the next generation is educating them by formal education. Through education gathered from school, a system of values and culture which are believed and applied in a particular society can be studied, developed, internalized, and transformed; that is why it is possible to continue to be sustainable. ${ }^{41}$ Education is the right institution because, in this phase, an individual is able to construct a foundation of knowledge and character so that it becomes a strong generation in the process at a higher level of education. ${ }^{42}$ One of the steps that can be implemented is designing a learning climate that creates a healthy climate, that is, no longer focus on competitiveness, but a climate that directs to cooperation. ${ }^{43}$

\section{Conclusion}

Kupatan tradition, which is held by the people of Plosokandang, Tulungagung every year, is an expression of gratitude to God after

\footnotetext{
${ }^{39}$ Mateja Pevec Rozman, "Role and Importance of Traditin in Contemporary Culture," Pregledni Znanstveni Članek 72, no. 4 (2012): 619-26, http://www.teof.unilj.si/uploads/File/BV/BV 2012 4/BV-72-4-Pevec Rozman.pdf.

${ }^{40}$ Joseph S. Nye Jr, Soft Power: The Means to Success in World Politics (New York: PublicAffairs, 2004).

${ }^{41}$ Ashif Az Zafi, "Transformasi Budaya Melalui Lembaga Pendidikan (Pembudayaan dalam Pembentukan Karakter)," Jurnal Ilmiah Ilmu Sosial dan Humaniora 3, no. 2 (2017): 105-12, https://doi.org/10.30738/sosio.v3i2.937.

42 Maswan Maswan, "Konstelasi Pendidikan Dasar dan Urgensinya dalam Pembentukan Generasi Penerus Bangsa," in Konstelasi Pendidikan dan Kebudayaan Indonesia di Era Globalisasi (Malang: Universitas Negeri Malang, 2017), http://pgsd.fip.um.ac.id/wp-content/uploads/2017/01/1.pdf.

43 M. Sastrapratedja, Sāstra Paddhati: Merajut Ilmu Humaniora (Yogyakarta: Universitas Sanata Dharma, 2013).
}

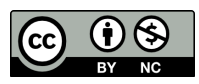

DOI: 10.19105/karsa.v29i1.3781 
fasting Shawwal for six days. In this activity, the people of Plosokandang distribute ketupat and other various traditional foods to other people who do not even know each other before. The value identified in this activity is the existence of harmony among society. Implementing a harmonious value is an important thing to apply, especially for a multicultural country like Indonesia.

Besides maintaining the existence of Kupatan tradition, another effort that can be made to internalize the values of harmony in every citizen is to replicate the value of harmony through formal education because education is the most effective medium for transforming a value system for the next generation.

\section{Bibliography}

Abdullah, Zaitun, and Endra Wijaya. "Efektifitas Pengaturan Masalah Kerukunan Umat Beragama dalam Peraturan PerundangUndangan di Indonesia." Pandecta: Jurnal Penelitian Ilmu Hukum 11, no. 2 (2016): 113-23. https://doi.org/10.15294/ pandecta.v11i1.783.

Ali, Muhamad. "Muslim Diversity: Islam and Local Tradition in Java and Sulawesi, Indonesia." Indonesian Journal of Islam and Muslim Societies 1, no. 1 (2011): 1-35. https://doi.org/10.18326/ ijims.v1i1.1-35.

Amin, Komarudin, and M. Arskal Salim. Ensiklopedi Islam Nusantara: Edisi Budaya. Jakarta: Direktorat Pendidikan Tinggi Keagamaan Islam, 2018.

Amin, Wildan Rijal. "Kupatan, Tradisi untuk Melestarikan Ajaran Bersedekah, Memperkuat Tali Silaturahmi, dan Memuliakan Tamu." Al-A 'raf: Jurnal Pemikiran Islam dan Filsafat 14, no. 2 (2017): 267. https://doi.org/10.22515/ajpif.v14i2.893.

Arif, Muhammad, and Melki Yandi Lasantu. "Nilai Pendidikan dalam Tradisi Lebaran Ketupat Masyarakat Suku Jawa Tondano di Gorontalo." Madani 1, no. 2 (2019). https://journal.iaingorontalo. ac.id/index.php/md/article/view/1068.

Arifin, Syamsul. Studi Agama, Perspektif Sosiologis dan Isu-Isu Kontemporer. Malang: UMM Press, 2009.

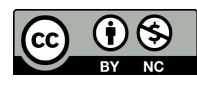

DOI: $10.19105 /$ karsa.v29i1.3781 
Arifudin, Iis. "Urgensi Pendidikan Multikultural di Sekolah." Insania: Jurnal Pemikiran Alternatif Pendidikan 12, no. 2 (2007). http:// ejournal.iainpurwokerto.ac.id/index.php/insania/article/view/252/ 222.

Aziz, Abd. "Desain Pendidikan Multikultural dalam Pendidikan Islam." Realita: Jurnal Penelitian dan Kebudayaan Islam 15, no. 1 (2017). https://jurnal.iainkediri.ac.id/index.php/realita/article/ view/461/297.

Aziz, Nur Hamzah. "Hari Raya Kupatan: Perspektif Filosofis dan SosioKultural Masyarakat Trenggalek.” IAIN Tulungagung, 2019.

Bhirawa, Danu. "Kupatan Massal Di Tulungagung Kian Meriah." Harian Bhirawa, 2019. https://www.harianbhirawa.co.id/Kupatan -massal-di-tulungagung-kian-meriah/.

Bigovic, Radovan. The Ortodox Church in 21 St Century. Belgrade: Foundatin Konrad Adenauer, 2009.

Budiwanti, Erni. Islam Sasak: Wetu Telu versus Waktu Lima. Yogyakarta: Penerbit LKiS, 2000.

Cahyono, R. Jati, and Yulianto Yulianto. "Tradisi Ritual Kupatan Jalasutra di Srimulyo, Piyungan, Bantul, Yogyakarta." Khasanah Ilmu 10, no. 2 (2019): 149-53. https://ejournal.bsi.ac.id/ejurnal/ index.php/khasanah/article/view/6647.

Faizal, Yusuf. "Nilai-Nilai Pendidikan Islam dalam Tradisi Punggahan dan Kupatan pada Masyarakat Dukuh Krangkeng Desa Grogolan Kecamatan Karanggede Kabupaten Boyolali Tahun 2014.” STAIN Salatiga, 2014.

Fidiyani, Rini. "Kerukunan Umat Beragama di Indonesia (Belajar Keharomonisan dan Toleransi Umat Beragama di Desa Cikakak, Kec. Wangon, Kab. Banyumas).” Jurnal Dinamika Hukum 13, no. 3 (2013). https://doi.org/10.20884/1.jdh.2013.13.3.256.

Geertz, Clifford. The Religion of Jawa. Chicago and London: The University of Chicago Press, 1976.

Harahap, Syahrin. Teologi Kerukunan. Jakarta: Prenada Media Media Group, 2011.

Hariyatmi, Sri. "Food: Invisible Bridge Connecting The Past and Present Day of Diasporic Identity." CELTIC: A Journal of

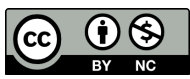

DOI: 10.19105/karsa.v29i1.3781 
Culture, English Language Teaching, Literature \& Linguistics 6, no. 2 (2019): 42-50. https://doi.org/10.22219/celtic.v6i2.9934.

Ismail, Radjiman. "Meningkatkan Sikap Toleransi Siswa Melalui Pembelajaran Tematik." Jurnal Ilmiah Pendidikan Islam Anak Usia Dini 2, no. 1 (2017).

Jirhanuddin. Perbandingan Agama. Yogyakarta: Pustaka Pelajar, 2005. Jr, Joseph S. Nye. Soft Power: The Means to Success in World Politics.

New York: PublicAffairs, 2004.

Kean, Ang Chooi, and Ngu Moi Kwe. "Meaningful Learning in the Teaching of Culture: The Project Based Learning Approach." Journal of Education and Training Studies 2, no. 2 (2014): 18997. https://doi.org/10.11114/jets.v2i2.270.

Koentjaraningrat. Kebudayaan: Mentalitas dan Pembangunan. Jakarta: PT. Gramedia Pustaka Utama, 2000.

Lubis, M. Ridwan. Cetak Biru Peran Agama. Jakarta: Puslitbang, 2005. Maswan, Maswan. "Konstelasi Pendidikan Dasar dan Urgensinya dalam

Pembentukan Generasi Penerus Bangsa." In Konstelasi Pendidikan dan Kebudayaan Indonesia di Era Globalisasi. Malang: Universitas Negeri Malang, 2017. http://pgsd.fip.um.ac. $\mathrm{id} /$ wp-content/uploads/2017/01/1.pdf.

McGowan, Jr., Carl B., and Noor Azzudin Jakob. "Is There An Eid AlFitr Effect In Malaysia?" International Business \& Economics Research Journal (IBER) 9, no. 4 (2010): 11-20. https://doi.org/ 10.19030/iber.v9i4.549.

Muhammad, Husein. Spiritualitas Kemanusiaan Perspektif Islam Pesantren. Bandung: Pustaka Rihlah, 2006.

Mulyawati, Wahyuni, and Ilse Harahap. Resep Andalan Resto Indonesia: Lontong \& Ketupat. Jakarta: PT. Gramedia Pustaka Utama., 2008.

Purna, Made, and Astuti Wahyuningsih. Mocopat Dan Gotong Royong. Jakarta: Putri Sejati Raya, 1996.

Purwanto, Yedi. "Memaknai Pesan Spiritual Ajaran Agama dalam Membangun Karakter Kesalehan Sosial." Jurnal Sosioteknologi 13, no. 1 (2014): 41. https://doi.org/10.5614/sostek.itbj.2014. 13.1.5.

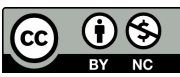

DOI: 10.19105/karsa.v29i1.3781 
Rianti, Angelina, Agnes E. Novenia, Alvin Christopher, Devi Lestari, and Elfa K. Parassih. "Ketupat as Traditional Food of Indonesian Culture." Journal of Ethnic Foods 5, no. 1 (2018): 4-9. https://doi. org/10.1016/j.jef.2018.01.001.

Ridwan, Nurma Ali. "Landasan Keilmuan Kearifan Lokal." Ibda: Jurnal Studi Islam Dan Budaya 5, no. 1 (2007): 27-38. https:// adoc.pub/landasan-keilmuan-kearifan-lokal-nurma-ali-ridwan.html.

Rozman, Mateja Pevec. "Role and Importance of Traditin in Contemporary Culture." Pregledni Znanstveni Članek 72, no. 4 (2012): 619-26. http://www.teof.uni-lj.si/uploads/File/BV/BV 20124/BV-72-4-Pevec Rozman.pdf.

Saleh, Samsubar, Dyah Titis Kusuma Wardani, and Madha Adi Ivantri. "Ramadhan, Eid Ul Fitr, and Inflation: Lesson From Indonesian Subnational Data." Jurnal Ekonomi \& Studi Pembangunan 20, no. 2 (2019): 135-50. https://doi.org/10.18196/jesp.20.2.5020.

Sastrapratedja, M. Sāstra Paddhati: Merajut Ilmu Humaniora. Yogyakarta: Universitas Sanata Dharma, 2013.

Satt, Harit. "Eid Mawlid Al-Nabi, Eid Al-Fitr and Eid Al-Adha; Optimism and Impact on Analysts' Recommendations: Evidence From MENA Region." Arab Economic and Business Journal 12, no. 1 (2017): 57-67. https://doi.org/10.1016/j.aebj.2017.04.001.

Sinaga, A. I. "Islamic Culture and Culture of Islam (As a Reflection in Rediscovering of Standard Absorption of Culture in Islamic Teaching)." Journal of Humanities and Social Science 21, no. 5 (2016): 90-95. https://doi.org/10.9790/0837-2105029095.

Soekanto, Suryono. Sosiologi: Suatu Pengantar. Jakarta: PT. Raja Grafindo, 2003.

Subagia, Rizky. "Makna Tradisi Kupatan Pada Masyarakat Desa Paciran, Kecamatan Paciran.” UIN Syarif Hidayatullah, 2018.

Suryana, Toto. "Konsep Dan Aktualisasi Kerukunan Antarumat Beragama." Jurnal Pendidikan Agama Islam: Ta'lim 9, no. 2 (2011). http://jurnal.upi.edu/file/03_KONSEP_DAN_AKTUALI SASI_KERUKUNAN_ANTAR_UMAT_BERAGAMA__TOTO.pdf.

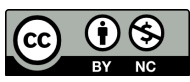

DOI: $10.19105 /$ karsa.v29i1.3781 
Weng, Hew Wai. "Beyond Chinese Diaspora" and "Islamic Ummah": Various Transnational Connections and Local Negotiations of Chinese Muslim Identities in Indonesia." Sojourn: Journal of Social Issues in Southeast Asia 29, no. 3 (2014): 627-56. https:// doi.org/10.1355/sj29-3d.

Yuhana, and Syamsul Bahri. "Tradisi Bulan Ramadhan dan Kearifan Budaya Lokal Komunitas Jawa di Desa Tanah Datar Kecamatan Rangat Barat Kabupaten Indragirihulu." JOM Fisip 3, no. 1 (2016): 1-15. https://jom.unri.ac.id/index.php/JOMFSIP/article/ view/7966/7638.

Yurike, Sherley, and Sukmawati Sukamulja. "Eid Al-Fitr Holiday Effect and The Relation Between Eid Al-Fitr Holiday Effect with The Firm Size During 2000 to 2013." Jurnal Ekonomi Manajemen Internasional 53, no. 9 (2013): 1-12. http://e-journal.uajy.ac.id/ 6986/1/JURNAL.pdf.

Yusuf, and Toet. Indonesia Punya Cerita : Kebiasaan dan Kebudayaan Unik yang Ada di Indonesia. Jakarta: Penebar Swadaya Group, 2012.

Zafi, Ashif Az. "Transformasi Budaya Melalui Lembaga Pendidikan (Pembudayaan dalam Pembentukan Karakter)." Jurnal Ilmiah Ilmu Sosial dan Humaniora 3, no. 2 (2017): 105-12. https://doi. org/10.30738/sosio.v3i2.937.

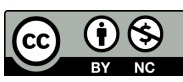

DOI: $10.19105 /$ karsa.v29i1.3781 